Metodički obzori 6(2011)1

Original scientific article

UDK: 371.3:811]:316.62-055.1/2

Received: 17. 6. 2010.

\title{
GENDER DIFFERENCES IN THE USE OF LEARNING STRATEGIES IN ADULT FOREIGN LANGUAGE LEARNERS
}

\author{
Nikolina Božinović, BA \\ American College of Management and Technology, \\ Dubrovnik (Croatia) \\ e-mail: nikolina@acmt.hr \\ Joško Sindik, PhD., \\ University of Dubrovnik, Dubrovnik (Croatia) \\ e-mail: josko.sindik@xnet.hr
}

\begin{abstract}
A b s tract
Learning strategies today represent a topical field of research in glottodidactics. Oxford (1990) defines them as specific actions taken by the learner to make learning easier, faster, more enjoyable, and more transferrable to new situations of language learning and use. Deployment of appropriate strategies ensures greater success in learning and more confidence. The first part of the paper lists the key definitions of learning strategies, while the second part presents the results of a quantitative survey that was conducted at the American College of Management and Technology in Dubrovnik on a sample of 181 respondents learning German, Spanish, French and Italian. The learning strategies were tested using a questionnaire based on Oxford's SILL (Strategy Inventory for Language Learning, Oxford, 1990). The survey was aimed at determining gender differences in the use of learning strategies and differences in the application of certain types of learning strategies. The results have shown that there are statistically significant differences in the frequency of the learning strategy use: memory strategies are most frequently used ones, while cognitive strategies are the least frequently used. However, there are gender differences in the use of learning strategies, where the female sex more frequently use all types of learning strategies, apart from socioaffective strategies. The final part of the paper lists the implications for teaching practice and provides guidelines for future research.
\end{abstract}

Keywords: learning strategies, communicative competence, success in learning, gender

\section{Introduction}

Foreign language learning strategies have been the subject of interest in the scientific research discipline studying the process of second language acquisition for 
several decades. When learning a foreign language, learners use a number of different strategies serving as a tool that helps learners to independently master the effectiveness of foreign language learning (Oxford and Nyikos, 1989; O'Malley and Chamot, 1990, Gardner and MacIntyre, 1993). The term "strategy" is differently defined in glottodidactic literature. Oxford (1990) defines language learning strategies as specific actions taken by the learner to make learning easier, faster, more enjoyable, and more transferrable to new situations of language learning and use. O'Malley and Chamot (1990) believe that these are special ways of processing information that enhance comprehension, learning, or retention of the information. Learning strategies assist learners in mastering the language forms and functions necessary for understanding and production in the second language acquisition (Rubin, 1981), while they also affect achievement (Bialystok, 1981, Oxford and Nyikos, 1989, Ehrman and Oxford, 1989, Bedell and Oxford, 1996, Dreyer and Oxford, 1996; Kaylani, 1996; Wharton, 2000; Bremner, 1999; Cohen, 1998; Hoang, 1999; O'Malley and Chamot, 1990; Yu, 2003; Shmais, 2003). The above-mentioned research indicates that the more successful learners use a larger number of strategies than the less successful learners. The element of choice seems to be one of the key features of learning strategies. Learners employ strategies intentionally with the aim of making learning more effective. They consciously choose the strategies that suit them most.

\section{The notion of learning strategies}

Learning strategies represent a topical field of research in glottodidactics and constitute one of the most significant individual differences among learners of foreign languages. Research of foreign language learning strategies began back in the nineteen seventies (Rubin, 1975; Savignon, 1972; Stern, 1975), while during the eighties and the nineties, learning strategies posed one of the most intriguing areas of study in foreign language learning (MacIntyre, 1994). The main research issues addressed by the researchers dealing with language learning strategies are related to the role of strategies in language acquisition, the connection of strategies to other individual traits of learners, such as learning style, attitude towards learning, motivation, foreign language anxiety and other factors, and to the impact of strategy instruction.

Various definitions of the learning strategies notion derive from the literature and the term itself has not been uniformly defined. In early works we can find a wide range of terms defining learning strategies, such as techniques, tactics, conscious plans, study skills, functional skills, cognitive abilities, while Oxford (1990) expands the array of terms by specifying the terms such as opinion-forming skills, reasoning skills, and the skill of "learning how to learn." Stern (1986) points out the difference between learning strategies as general features of learning approach and techniques as specific procedures. The dichotomy between strategies and techniques does not realistically exist today, while techniques as specific processes are considered to be individual learning strategies. Learning strategies 
tend to be mental processes over which students have conscious control and which they can choose to use when performing tasks (O'Malley and Chamot 1990; Chamot, 1996 in Gimeno, 2002). Chamot (1987, in Gimeno, 2002) states that learning strategies are techniques, approaches or deliberate actions that students take in order to facilitate learning, recall of both linguistic and content area information. Wenden (1991) pointed out the importance and role of metacognition in foreign languages learning, making a difference between metacognitive knowledge, i.e. what learners know about learning a foreign language, and the metacognitive strategies, as a way in which learners plan and regulate their own knowledge. The same author believes that strategies are mental steps or operations that learners use to learn a new language and to regulate their efforts to do so. Weinstein and Mayer (in O'Malley and Chamot, 1990) see strategies as behaviours or thoughts that a learner engages in during learning that are intended to influence the learners' encoding process. Oxford (1990) defines strategies as behaviours or specific actions taken by the learner to make learning easier, faster, more enjoyable, more selfdirected, more efficient, and more transferable to new situations. Ellis (1995), however, states that strategies are related to some kind of mental activity or behaviour that can occur in a particular phase of the learning and communication process. Cohen (1998) emphasizes that these are operations selected by the learner part consciously in order to enhance learning or use of an L2, through storage, recall and application of information about that language.

Early studies of learning strategies are associated with the strategies used by good foreign language learners. Good language learners have a wide repertoire of learning strategies and use a series of strategies, rather than a single one, when engaged in a learning task. One fact is obvious - good language learners use a larger number of strategies in the process of foreign language learning, unlike not so successful learners (Rubin, 1975, Bialystok, 1979, in Gimeno, 2002; O'Malley and Chamot, 1990; McDonough, 1999 and Skehan, 1989 in Harris and Grenfell, 2004). Their purpose is to help less successful learners to master strategies used by good learners (Hosenfeld, 1979, Bialystok, 1984, Faerch and Kasper, 1983, Oxford, 1989, in Gimeno, 2002). In this context it is necessary to emphasize the importance of learning strategy instruction (Oxford and Nyikos, 1989, in Gimeno, 2002). The importance of explicit strategy instruction is also highlighted by many researchers. Wenden (1998) believes that strategy training will be much more effective if learners are informed about the value and purpose, and a possible transfer to nonlinguistic tasks. A similar attitude is expressed by Oxford (1990), Cohen (1998), O'Malley and Chamot (1990) who stated that explicit strategy instruction involves the raising of students' awareness of the strategies they use, modelling of strategic thinking, naming of individual strategies, practice and student self-evaluation. The aim of explicit strategy instruction and the development of individualized strategy systems refers to the help provided to learners in raising their awareness of the strategies they already use and to the encouragement to develop a set of new, adequate and effective strategies within a particular language context. Another objective of strategy instruction is to encourage leaner's autonomy and selfdirection, to enable learners to choose their own strategies in a spontaneous way, 
without constant teacher's intervention. Learners should be able to oversee and evaluate the effectiveness of strategy use and to develop problem-solving skills. The teacher can teach strategies and practice them, but each learner is individually responsible for the selection and implementation of an adequate strategy. A learner will select a strategy that suits him/her best and the focus is on how to learn and not what you learn. Oxford (1990) believes that the main purpose of strategic training is to make language learning effective, to foster team spirit among learners and teachers, to learning to learn language and how to practice strategies that raise selfconfidence.

There is a significant link between the use of various learning strategies applied by foreign language learners and their learning achievement (Chamot and Kupper, 1989). Good language learners use a large number of effective learning strategies, unlike the less successful learners (Hosenfeld, 1977). Good learners are also able to select and combine strategies that are appropriate to the task at hand (Vann and Abraham, 1990). It is evident that successful learners combine certain cognitive strategies (translation, analysis, noting) with specific metacognitive strategies (self-evaluation, planning and organizing) (Oxford and Crookall, 1989). Less successful learners use fewer strategies, as opposed to successful learners, and their strategies are limited by the type of strategy to a large extent (Nyikos, 1987, in Gimeno, 2002). Often, less successful learners are not aware of the strategies they use (Nyikos, 1987, in Gimeno, 2002). If a less successful learner is aware of his/her use of strategies, he/she can combine them and use them in a successful way (Lavine and Oxford, 1990). Stern (1975) conducted a very interesting study of good foreign language learners and identified learning strategies used by good learners. For good learners, according to Stern (1975), personal learning style, i.e. encouragement of positive learning strategies is of great importance, as well as an active approach to the learning task, a tolerant approach to the target language, and empathy with the speaker. Stern (1975) also mentioned the importance of the technical know-how of how to tackle a language, the importance of experimentation and planning strategies in an attempt to develop the target language into an ordered system, and the willingness to constantly revise that system.

\section{The taxonomy of learning strategies}

One of the most prominent authors dealing with the issue of learning strategies is certainly the American psychologist Rebecca Oxford who constructed one of the most popular instruments for measuring learning strategies, the so-called SILL (Strategy Inventory for Language Learning) in 1990, which was validated in numerous languages and cultures around the world.

The taxonomy of learning strategies proposed by Oxford (1990) comprised six categories of learning strategies and the author classified them into direct and indirect strategies. The author included memory, cognitive and compensation strategies into the category of direct strategies, while the indirect strategies include 
metacognitive, affective and social strategies. Indirect strategies do not directly affect the target language, but have a significant role in language learning. Classification provided by Oxford was subjected to criticism, primarily because it was not based on factor analysis and achievements of cognitive science. In addition, no clear distinction between the strategies of language use and strategies of language learning had been established. Many strategy researchers (Dörnyei, 2005, Purpura, 1999, in Dörnyei, 2005) do not believe that 'compensation' strategies belong to the language learning strategies, but communication strategies, and that it is problematic to separate communication strategies from memory strategies since the memory strategies actually constitute a subclass of cognitive strategies. This separation was motivated by the observation that most memory strategies (especially mnemonic devices, such as imagery, rhyming, and keywords) are associated with shallow processing, whereas most cognitive strategies are associated with deep processing (Dörnyei, 2005).

Nowadays the most widely accepted classification of learning strategies was offered by O'Malley and Chamot (1990), which is actually similar to the classification proposed by Oxford (1990). O'Malley and Chamot (1990) differentiate between cognitive, metacognitive and social/affective strategies. Cognitive strategies correspond to Oxford's (1990) memory strategies and cognitive strategies, metacognitive strategies are a direct equivalent to Oxford's system, while social/affective strategies correspond to Oxford's social, affective and communication strategy categories. The empirical analysis conducted by Hsiao and Oxford (2002) confirmed that the explanatory power of the model proposed by O'Malley and Chamot (1990) would be increased, provided that the social/affective strategies were classified as distinct groups of strategies. However, literature usually classifies social and affective strategies as a common group of strategies, and they are called socio-affective strategies. We can conclude that the typology of strategies proposed by Oxford (1990) and O'Malley and Chamot (1990) is highly compatible, Dörnyei (2005) emphasized that the compatibility would be important if three changes were made, namely if communication strategies were excluded from the framework of learning strategies, if Oxford memory strategy and cognitive strategy were combined, and if social/affective strategies were separated as proposed by O'Malley and Chamot (1990). This is why Dörnyei (2005) proposes a typology of strategies that includes four main components of strategies: cognitive strategies (1) that include a specific manipulation or transformation of material to be learned, i.e. language input, such as repetition of material, summarizing of information, use of mnemonics, etc.; metacognitive strategies (2) as higher-order strategies which comprise analysis, monitoring, evaluation, planning and organizing one's own learning process; social strategies (3) which include interaction with other learners, the goal of which is to increase the amount of L2 communication and practice in a foreign language (initiating interaction with native speakers, cooperation with peers); affective strategies (4) which include the user's control over one's own emotions and experiences that reflect the user's subjective involvement in the learning process. 
According to the interpretations of researchers there is no clear boundary between the metacognitive and cognitive strategies; therefore, most researchers agree that the metacognitive strategies are executive and cognitive strategies are operational strategies (O'Malley and Chamot, 1990). The above implies that metacognitive strategies include thinking about the learning process, planning of learning, observation of understanding or production, and self-evaluation of learning. On the other hand, cognitive strategies refer to direct and specific tasks in the learning process and involve a direct manipulation or transformation of the content learned. Cohen and Dörnyei (2002) point out to the extreme importance of metacognitive strategies and define them as processes which learners consciously use to oversee their own learning and manage it. Metacognitive strategies allow you to control your own cognition so that learners plan their activities, check them and then evaluate. Numerous studies were conducted in the area of metacognitive and cognitive strategies, and their application and transfer to the new language tasks. The importance of metacognitive strategies crucial for successful learning has been emphasized in these studies. Learners who do not have a metacognitive approach or do not know how to apply it remain without a real goal and direction, without the possibility of planning their own learning, monitor their own progress and their achievements, and future goals of learning (O'Malley and Chamot, 1990).

\section{Characteristics of learning strategies}

Oxford (1990) lists the basic features of learning strategies emphasizing that strategies are oriented towards the development of communication competence in a foreign language and include interaction between learners. Oxford (1990) lists 12 basic features of a foreign language learning strategy:

1. strategies contribute to the main goal - communicative competence;

2. strategies allow learners to become more self-directed and to develop autonomous learning and take responsibility for their own learning; they affect the process of learning, the learner's success or failure in learning;

3. strategies expand the role of foreign language teachers in a way that the traditional role of the teacher in the educational process changes and the teacher assumes the role of person facilitating the learning, helping, advising, diagnosing, coordinating learning, and participating in communication;

4. strategies are problem-oriented;

5. strategies are specific actions taken by the learner;

6. in addition to the cognitive, strategies involve many other aspects of learning, such as metacognitive, affective and social aspects;

7. support learning, both directly and indirectly;

8. strategies are not always observable, they can be concealed;

9. strategies are often conscious; 
10. strategies can be taught;

11. strategies are flexible;

12. strategies can be influenced by a variety of factors.

Learning strategies have been studied from different perspectives, based on which it was concluded that numerous individual variables affect the selection of learning strategies, such as gender, age, motivation for language learning, cognitive learning style, maturity level, previous experience in language learning, learner's beliefs and other factors. Therefore, strategies are the cause of differences among learners and they interact with the aforementioned variables as personality traits. Cohen and Dörnyei (2002) believe that the most important individual differences among learners relate to their age and gender.

\section{Gender differences in the use of learning strategies}

Numerous empirical researches have shown that gender has a significant effect on the extent of strategy use. Women use learning strategies more often than men (Dreyer \& Oxford, 1996; Green \& Oxford, 1995; Lan \& Oxford, 2003; Lee \& Oh, 2001; Oxford \& Ehrman, 1995; in Lee and Oxford, 2008). Results of the research carried out by Oxford et al. indicate that gender has a significant effect on the frequency of strategy use. The research findings indicate that women more frequently use memory, cognitive and social strategies. Oxford and Nyikos (1989) examined the use of learning strategies on a sample of 1200 adult French, Spanish, Italian and German language learners and demonstrated that gender plays a decisive role in the selection of strategies. The research results show that women tend to deploy all types of strategies more frequently, which corresponds to the results of previous researches on the role of gender in foreign language learning. These findings were also replicated in the research conducted by Ehrman and Oxford (1989) on a sample of 78 adult learners, including students and professors at the faculties of philological studies. The languages covered by the research included Indonesian, Turkish, Italian, Hungarian and Arabic. In accordance with the previous research, gender differences in the use of strategies were revealed. It was shown that female respondents used general learning strategies more often, and authentic strategies, strategies of getting and communicating meaning, as well as self-direction strategies were more frequently deployed by female respondents.

The research carried out by Zimmerman and Martinez-Pons (1990, in Lee \& Oxford, 2008) has found that females use metacognitive strategies as planning and monitoring strategies. As regards gender differences in the use of learning strategies, some studies indicate that the connection between strategy use and gender appears to be blurred (Dadour \& Robbins, 1996; Oh, 1996; Park, 1999 in Lee \& Oxford, 2008). Kaylani (1996) has found that male students differ from their female counterparts in the extent of strategy use. She has found that female students use memory, cognitive, compensation and affective strategies more frequently than male students 
and thus the correlation between gender and language proficiency has been established.

Dongyue (2004) carried out quite an interesting research on the correlation between language proficiency, gender and strategy use. The research findings indicate that there are statistically significant gender differences in memory, affective and overall strategy use in favour of females. The results indicate that females are better at managing and controlling their emotions than their male counterparts. The author also points out that the difference in the frequency of strategy use between men and women may be affected by other variables such as ethnic background, cultural background and language learning environment.

\section{Survey on gender differences in the use of learning strategies in adult foreign language learners}

\section{Survey objectives}

In accordance with the aforementioned researches conducted by the foreign authors, our survey was aimed at identifying gender differences in the frequency of learning strategy use following the classification suggested by Oxford. Additionally, we were also interested in the differences in the frequency of learning strategy use in general, regardless of the gender. We assumed there were some gender differences in the overall learning strategy use in favour of females. We also assumed that there were some differences in the extent to which learning strategies were used by the students who participated in the survey.

\section{Methodology}

\section{Instrument}

Learning strategy use was examined by means of a learning strategy questionnaire designed by the paper author who adapted some of the items from Rebecca Oxford's SILL questionnaire (Strategy Inventory for Language Learning, 1990). The questionnaire contains 55 items corresponding to individual foreign language learning strategies and a three-point scale was used for evaluating the degree of strategy use frequency (1- 'never true of me', 3- 'always or almost always true of me'). The questionnaire also provided some demographic data on the respondents (gender, age, language learning level, mother tongue and evaluation). We excluded compensation strategies from the survey questionnaire having in mind widespread criticism that compensation strategies do not really belong to learning strategies. Oxford's original SILL questionnaire has also attracted criticism because it was not confirmed in terms of factor (construct) validity, so we tried to analyze it as well. Since solutions found through different varieties of factor analysis by component analysis and axis factoring using orthogonal and oblique rotations 
generated dimensions at which there is interference between three or more learning strategies, we considered that it would be more valid to see whether items which theoretically described a strategy covered sufficiently only this particular strategy in metrical terms. With this in view, the questionnaire was further divided into subquestionnaires containing items which described particular learning strategies in accordance to Oxford's strategies. Afterwards, we established metric characteristics of each questionnaire dimension by performing a component analysis with a preassumption that each of the dimensions (which hypothetically corresponded to individual learning strategies: social, affective, memory, metacognitive and cognitive) had one component structure. The memory strategy use questionnaire (11 items) was found to be sufficiently reliable (Cronbach $\alpha=.60$ ), explaining only $21.84 \%$ of the total variance for the memory strategy dimension. Cognitive strategy sub-questionnaire (10 items) was found to be sufficiently reliable (Cronbach $\alpha=.76$ ), explaining only $32.34 \%$ of the total variance for the cognitive strategy dimension. Metacognitive strategy sub-questionnaire (12 items) was found to be sufficiently reliable (Cronbach $\alpha=.77$ ), explaining only $29.39 \%$ of the total variance for the metacognitive strategy dimension. However, social strategy use sub-questionnaire (3 items) and affective strategy use sub-questionnaire (4 items) proved not to be sufficiently reliable: Cronbach $\alpha=.37$ and Cronbach $\alpha=.38$, respectively. Thus, items of the two strategies were «fused» into one socio-affective strategy use questionnaire (7 items) with a lower, but satisfactory reliability (Cronbach $\alpha=.52$ ), explaining only $26.21 \%$ of the total variance for socio-affective strategy dimension. By linear combination of items defining individual dimensions, we obtained complete results for each learning strategy. In order to facilitate comparison, these results were divided by the number of items defining particular dimension (learning strategy).

\section{Sample}

A total of 181 respondents attending American College of Management and Technology in Dubrovnik participated in the survey. There were 72 male $(40 \%)$ and 109 female $(60 \%)$ respondents. 58 of them $(32.3 \%)$ were at the beginner level, while 123 of them $(67.7 \%)$ were at an intermediate foreign language level. 159 respondents $(88 \%)$ were native Croatian speakers, while 22 respondents $(12 \%)$ were native speakers of one of the following languages: Bosnian, Macedonian, Montenegrin, Albanian, Serbian, English and German. 172 respondents (95.5\%) said English was their second language. 36 respondents (19.9\%) learned German as their second language, 56 respondents (30.8\%) learned Spanish as their second language, 51 respondents $(28.4 \%)$ learned Italian as their second language and 38 of them (20.9\%) said French was their second language. As regards their success in second language learning, 68 respondents $(37.8 \%)$ said that in the last quarter they achieved an A in foreign language class, 44 respondents $(24.4 \%) \mathrm{B}, 15$ respondents $(8.5 \%) \mathrm{C}$, and 7 respondents $(4 \%) \mathrm{D}$. 


\section{Data collection and analysis}

The data were collected during regular foreign language classes at the College. Respondents were not informed beforehand that the survey would be carried out. The tests were anonymous, in order that the respondents could give honest answers to the questions.

Data analysis was performed using descriptive statistics and Pearson's correlation coefficient in order to establish intercorrelation among questionnaire dimensions (in this case the total results of the sub-questionnaires). Gender differences were established by discrimination analysis, while the differences in the frequency of individual learning strategy use between male and female respondents were established by t-test for dependent samples. The data from the questionnaire were analyzed using the SPSS 11.0 statistical program.

\section{Results and discussion}

Frequency of individual strategy use was established by descriptive analysis of learning strategies according to Oxford's classification. As shown in Table 1, memory strategies are the most frequently used, while cognitive strategies are the least frequently used by the respondents.

Table 1 Descriptive statistics for dimensions of learning strategies

\begin{tabular}{|l|c|c|c|c|l|}
\hline Learning strategies & $\mathrm{M}$ & $\mathrm{SD}$ & Min & Max & \\
\hline Memory strategies & 2.3112 & .2806 & 1.36 & 2.91 & \\
\hline Socio-affective strategies & 2.1905 & .3376 & 1.00 & 3.00 & \\
\hline Metacognitive strategies & 1.8765 & .3318 & .92 & 2.75 & \\
\hline Cognitive strategies & 1.8020 & .3972 & 1.00 & 2.90 & \\
\hline
\end{tabular}

As indicated in Table 2, all correlations among learning strategies are statistically significant $(\mathrm{p}<.01)$, positive and medium ones. The greatest correlation was found between the cognitive and metacognitive strategies, which are essentially very similar, as well as between the memory and metacognitive strategies. The lowest correlation, though significant and positive, was found between the socioaffective and cognitive strategies.

Statistically significant differences as regards strategy prevalence were found among all learning strategies. The greatest differences were found between memory and metacognitive strategies, where metacognitive strategies were less frequently used. Almost equally significant differences were found between memory and cognitive strategies. In view of the criticism of Oxford's taxonomy, it is possible that memory strategies are part of cognitive learning strategies and that these differences don't really exist, since the difference between the strategies might be artificial rather than actual. Similarly it could be said of the smallest difference (although it is 
statistically a significant one) found in strategy prevalence among cognitive and metacognitive learning strategies, which are also very similar.

Table 2 Differences and correlations among learning strategy use frequency (t-test for dependent samples and Pearson's correlation)

\begin{tabular}{|c|c|c|c|c|c|c|}
\hline & 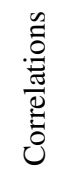 & 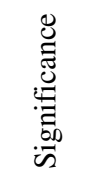 & 焉 & 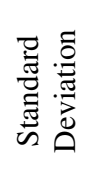 & $\mathrm{t}$ & 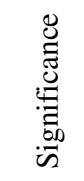 \\
\hline Memory /Socio-affective & .561 & $\mathrm{p}<.01$ & .1207 & .2941 & 5.819 & $\mathrm{p}<.01$ \\
\hline Memory/ Metacognitive & .612 & $\mathrm{p}<.01$ & .4347 & .2737 & 22.515 & $\mathrm{p}<.01$ \\
\hline Memory/Cognitive & .503 & $\mathrm{p}<.01$ & .5092 & .3526 & 20.475 & $\mathrm{p}<.01$ \\
\hline Socio-affective/Metacognitive & .528 & $\mathrm{p}<.01$ & .3140 & .3252 & 13.689 & $\mathrm{p}<.01$ \\
\hline Socio-affective /Cognitive & .388 & $\mathrm{p}<.01$ & .3885 & .4094 & 13.452 & $\mathrm{p}<, 01$ \\
\hline Metacognitive/Cognitive & .650 & $\mathrm{p}<.01$ & .0745 & .3106 & 3.399 & $\mathrm{p}<.01$ \\
\hline
\end{tabular}

As shown in Table 3, canonical correlation coefficient representing the extent of correlation between inclusion into individual sub-sample and results of the discrimination function is 0.346 , which makes it medium-high. Wilks' lambda (0.880) indicates that, based on the discrimination function, there is statistically a significant difference between respondents according to gender and they can therefore be differentiated based on the modified dimensions of Oxford's learning strategies. For female respondents group centroids are 0.301 and for male respondents -0.447 . The values of the structure coefficients, which indicate the correlation of the individual discrimination variable with discrimination function, vary between 0.058 and 0.738 . Results of the univariate analysis of variances for individual dimensions of learning strategies indicate that based on the discrimination function statistically significant differences among students exist in memory, metacognitive and cognitive strategies, while there is no statistically significant difference in socio-affective learning strategies. Based on the discrimination function, $63.2 \%$ of accurate classification of respondents can be made. Thus, female respondents (students) use all strategies more frequently, except for the socioaffective ones. Our results have confirmed our initial hypotheses developed on the basis of previous research (Dreyer and Oxford, 1996; Green and Oxford, 1995; Lan and Oxford, 2003; Lee and Oh, 2001; Oxford and Ehrman, 1995, in Lee and Oxford, 2008).

Statistical analysis of the survey results has provided the answers to the basic survey questions as to whether there are gender differences both in the use of learning strategies and in the use of particular types of learning strategies. The survey results have confirmed that there are gender differences in the use of learning strategies and that female respondents use all strategy types more frequently than their male counterparts, except for the socio-affective ones. As regards the use of particular learning strategy types, it has been confirmed that there is statistically significant difference in the frequency of strategy use: memory strategies are the 
most frequently used strategies, while cognitive strategies are the least frequently used. The survey results have also shown a medium positive correlation among all types of learning strategies $(\mathrm{p}<.01)$. The greatest correlation was found between cognitive and metacognitive strategies, and between memory and metacognitive strategies. Therefore we can assume that there are no clear cut boundaries between cognitive and metacognitive strategies, or between memory and metacognitive strategies, which are essentially very similar. The lowest correlation, although statistically significant and positive, was found between socio-affective and cognitive strategy, which indicates that these are different learning strategies. According to Oxford, cognitive strategies belong to the group of direct strategies which have an operational function and help a student understand the material to be learned, while socio-affective strategies belong to the group of indirect strategies which allow a student to interact with other participants in the teaching/learning process and are oriented towards the development of self confidence and perseverance necessary for successful language learning.

Table 3 Results of discrimination analysis of individual dimensions from the Questionnaire on learning strategies according to the respondents' gender

\begin{tabular}{|c|c|c|c|c|c|c|c|c|}
\hline $\begin{array}{r}\text { Significance } \\
\text { discrimination }\end{array}$ & $\begin{array}{l}f \text { the } \\
\text { unction }\end{array}$ & Eigenvalue & Wilks' la & mbda & $\begin{array}{l}\text { Cano } \\
\text { correl }\end{array}$ & & \begin{tabular}{|c}
$\chi^{2}$ \\
(degrees \\
of \\
freedom) \\
\end{tabular} & $\mathrm{p}$ \\
\hline Discriminatior & unction & .136 & .880 & & .3 & & 25.109 (4) & $<.01$ \\
\hline VARIABLE & $\begin{array}{c}\text { Wilks' } \\
\text { lambda }\end{array}$ & $\begin{array}{c}\text { Correlation } \\
\text { with } \\
\text { discrimination } \\
\text { factor }\end{array}$ & $\begin{array}{c}\text { F-test } \\
(1.199)\end{array}$ & $\mathrm{p}$ & $\begin{array}{c}\mathrm{M} \\
\text { male }\end{array}$ & $\begin{array}{c}\sigma \\
\text { male }\end{array}$ & $\begin{array}{c}\text { M } \\
\text { female }\end{array}$ & $\begin{array}{c}\sigma \\
\text { female }\end{array}$ \\
\hline Memory & .937 & .704 & 13.406 & $<, 01$ & 2.2256 & .2735 & 2.3689 & .2714 \\
\hline Socio-affective & 1.000 & .058 & .092 & $>.20$ & 2.1817 & .3557 & 2.1964 & .3261 \\
\hline Metacognitive & .950 & .625 & 10.564 & $<.01$ & 1.7860 & .3211 & 1.9375 & .3261 \\
\hline Cognitive & .931 & .738 & 14.747 & $<.01$ & 1.6753 & .3855 & 1.8875 & .3834 \\
\hline
\end{tabular}

Legend: $M=$ arithmetic mean; $\sigma=$ standard deviation

The results also suggest that there are statistically significant gender differences in the frequency of overall learning strategy use. The greatest differences were found between memory and metacognitive strategies, while the use of metacognitive strategies by our respondents was quite rare. We can assume that our respondents lack sufficient intrinsic motivation for foreign language learning and therefore the use of metacognitive strategies, which are used to self-direct, plan, focus or evaluate language learning progress, was quite rare. One of the reasons might be that our respondents lack capacity to use metacognitive strategies as "high ranking" skills. This indicates that there is a need to systematically teach adequate metacognitive learning strategies which encourage autonomous learning, extend the level of language awareness and contribute to the success in foreign language learning. Equally great differences were found between memory and cognitive 
strategies which undoubtedly indicates that memory strategies belong to the category of cognitive learning strategies.

\section{Conclusion}

The aim of the survey was to provide an insight into the learning strategies that adult learners of German, Spanish, French and Italian mostly use, as well as to establish gender differences in strategy use. The results of the survey have confirmed both of our initial hypotheses. The results suggest that there is statistically significant difference in the frequency of strategy use. Memory strategies are the most frequently used, while cognitive strategies are the least frequently used. Additionally, the survey findings have confirmed that learning strategy use differs by gender. The findings of our survey revealed that female students used all learning strategies more frequently than their male counterparts, with the exception of socioaffective strategies, which corresponds to the findings of previous researches. Since this survey has indicated that the frequency of metacognitive strategy use is quite low, it seems necessary to raise students' awareness of the strategies they use. Teaching students how to use learning strategies allows them to find their own strategy of successful language learning and to develop autonomy as well as selfdirection strategies in the process of foreign language learning. Explicit strategy instruction plays a key role in foreign language learning among adults. Adequate learning strategy use leads to more successful learning results. It would be beneficial to investigate some other aspects of learning strategy use, such as the differences in strategy use according to individual languages, as well as the cultural influences on the use of learning strategies. These are just some of the aspects that could be covered in future research.

\section{References}

Bedell, D. and Oxford, R.L. (1996), Cross-cultural comparisons of language learning strategies in the People's Republic of China and other countries. In R.L. Oxford (ed.), Language learning strategies around the world: Cross-cultural perspectives (Tech. Rep. No. 13, pp. 47-60). Honolulu. HI: University of Hawai'i Press.

Bialystok, E. (1981), The role of conscious strategies in second language proficiency, Modern Language Journal, 65 (1), 24-35.

Bremner, S. (1999), Language learning strategies and language proficiency: investigating the relationship in Hong Kong. Canadian Modern Language Review, 55 (4), UTPJOURNALS online. http://UTPJOURNAL.com. Accessed March, 2010.

Chamot, A. and Kupper, L. (1989), Learning Strategies in Foreign language Instruction. Foreign language Annals, 22, 13-24.

Cohen, A.D. (1998), Strategies in Learning and Using a Second Language. New York: Addison Wesley Longman. 
Cohen, A.D. and Dörnyei, Z. (2002), Focus on the language learner: Motivation, styles, and strategies. In N. Schmitt (eds), An introduction to applied linguistics (pp. 170-190). London: Arnold.

Dongyue, L. (2004), EFL Proficiency, Gender and Language Learning Strategy Use Among a Group of Chinese Technological Institute English Majors. Arecls E-Journal, 1 (A5).

Dörnyei, Z. (2005), The Psychology of the Language Learner. Individual differences in Second Language Acquisition. London: Lawrence Erlbaum Associates, Inc.

Dreyer, C. and Oxford, R. L. (1996), Learning Strategies and other predictors of ESL proficiency among Afrikaans speakers in South Africa. In R. L. Oxford (ed.), Language learning strategies around the world: Cross-cultural perspectives (Tech. Rep. No. 13, pp. 61-74). Honolulu, HI: University of Hawai' i Press.

Ellis, R. (1995), The study of Second Language Acquisition. Oxford: Oxford University Press.

Ehrman, M. and Oxford, R. (1989), Effects of sex differences, career choice, and psychological type on adult language learning strategies. The Modern Language Journal 73 (1), 113.

Gardner, R.C. and MacIntyre, P.D. (1993), A student's contribution to second-language learning. Part II: Affective Variables. Language Teaching, 26, 1-11.

Gimeno, V. V. (2002), Grammar Learning through Strategy Training: A Clasroom Study on Learning Conditionals through Metacognitive and Cognitive Strategy Training, doctoral dissertation, https://proxy.knjiznice.ffzg.hr - Accessed October, 2009.

Harris, V. and Grenfell, M. (2004), Language Learning Strategies: A Case for Crosscurricular Collaboration. Language Awareness, 13 (2), 116-130.

Hoang, L.T. (1999), Research into language learning strategies of different groups of learners in Hue City. In The 4-th international conference on language learning and development. Vietnam: The Ministry of Education and Training.

Hosenfeld, C. (1977), A Preliminary Investigation of the Reading Strategies of Successful and Unseccessful Second Language Learners. System, 4, 116-123.

Hsiao, T.-Y. and Oxford, R.L. (2002), Comparing Theories of Language Learning Strategies: A Confirmatory Factor Analysis, The Modern Language Journal, 86 (2), 368-383.

Kaylani, C. (1996), The influence of gender and motivation of EFL learning strategy use in Jordan. In R. Oxford, (ed.) Language Learning Strategies Around the World: Cross-cultural perspectives (pp. 75-88). Honololu: University of Hawai'i: Second Language Teaching and Curriculum Center.

Lavine, R.E. and Oxford, R.L. (1990), Dealing with affective issues in the foreign or second-language classroom. Modern Language Association Annual Meeting, Chicago.

Lee, K.R. and Oxford, R.L. (2008). Understanding EFL Learner's Strategy Use and Strategy Awareness. Asian EFL Journal, 10 (11), 7-32.

MacIntyre, P.D. (1994), Toward a social psychological model of strategy use. Foreign Language Annals, 27, 185-195.

O'Malley, J.M. and Chamot, A.U. (1990), Learning Strategies in Second Language Acquisition. New York: Cambridge University Press.

Oxford, L.R. (1990), Language Learning Strategies: What Every Teacher Should Know. Boston: Heinle and Heinle Publishers.

Oxford, R.L. and Crookall, D. (1989), Research on Language Learning Strategies: Methods, Findings and Instructional Issues. Modern Language Journal, 73, 404-419. 
Oxford, R.L. and Nyikos, M. (1989), Variables affecting choice of language learning strategies by university students. Modern Language Journal, 75, 292-300. 51.

Rubin, J. (1975), What the 'good language learner' can teach us? TESOL Quarterly, 9, 41-

Rubin, J. (1981), „The study of cognitive processes in Second Language Acquistion", Applied Linguistics, 2, 117-131.

Savignon, S.J. (1972), Communicative competence: An experiment in foreign-language teaching. Philadelphia, PA: The Center for Curriculum Development.

Shmais, W.A. (2003), Language learning strategy use in Palestine. TESL-EJ 7(2), A-3.

Stern, H.H. (1975), What can we learn from the good language learner? Canadian Modern Language Review, 31, 304-318.

Stern, H.H. (1986), Fundamental Concepts of language Teaching. Oxford: Oxford University Press.

Vann, R. and Abraham, R. (1990), Strategies of Unsuccessful Language Learners. Paper presented at the 24th Annual TESOL Convention. San Francisco, CA. March, 199909.

Wenden, A. (1991), Learner Strategies for Learner Autonomy, New York: Prentice Hall

Wenden, A. (1998), Learner Strategies in Language Learning. Great Britan: Prentice Hall.

Wharton, G. (2000), Language learning strategy use of bilingual foreign language learners in Singapore. Language Learning, 50 (2), 203-244.

$\mathrm{Yu}, \mathrm{L}$. (2003), Learning strategies and their relationship to listening comprehension. A report on Non-English majors in a medical university in China. Teaching English in China, 26 (4), 3-11.

Metodički obzori 6(2011)1 Izvorni znanstveni rad

UDK: 371.3:811]:316.62-055.1/2 Primljeno: 17. 6. 2010.

\title{
SPOLNE RAZLIKE U UPORABI STRATEGIJA UČENJA KOD ODRASLIH UČENIKA STRANOGA JEZIKA
}

\author{
Nikolina Božinović, prof. \\ Američka visoka škola za management i tehnologiju, Dubrovnik (Croatia) \\ nikolina@acmt.hr \\ dr. sc. Joško Sindik \\ Sveučilište u Dubrovniku, Dubrovnik (Croatia) \\ e-mail: josko.sindik@xnet.hr
}

Sa žetak

Strategije učenja danas predstavljaju aktualno područje ispitivanja u glotodidaktici. Oxford (1990) ih definira kao specifične aktivnosti koje učenik poduzima kako bi proces učenja učinio lakšim, bržim i ugodnijim te kako bi iste mogao primijeniti u novim situacijama učenja i uporabe jezika. Primjena prikladnih strategija osigurava veći uspjeh u učenju i veću sigurnost. U prvom 
dijelu rada navedene su ključne definicije pojma strategija učenja, dok su u drugom dijelu predstavljeni rezultati kvantitativnog istraživanja koje je provedeno na Američkoj visokoj školi za management i tehnologiju u Dubrovniku na uzorku koji je obuhvatio 181 ispitanika njemačkog, španjolskog, francuskog i talijanskog jezika. Za ispitivanje strategija učenja korišten je upitnik koji se temelji na Oxfordinom SILL-u (Strategy Inventory for Language Learning, Oxford, 1990). Ciljevi istraživanja bili su utvrditi spolne razlike u uporabi strategija učenja, te razlike u uporabi pojedinih tipova strategija učenja. Rezultati su pokazali da se strategije učenja statistički značajno različito često koriste: najčešće se koriste strategije pamćenja, a najrjeđe kognitivne strategije. S druge strane, postoje spolne razlike u uporabi strategija učenja, gdje se ženski spol češće koristi svim tipovima strategija učenja, osim društveno-afektivnim. U završnom dijelu navode se implikacije za nastavnu praksu, te se daju smjernice za buduća istraživanja.

Ključne riječi: strategije učenja, komunikacijska kompetencija, uspjeh u učenju, spol 